Gi respons på artikler gjennom artiklenes kommentarfelt på tidsskriftet.no. Innleggene publiseres fortløpende på Tidsskriftets nettside og et utvalg av innleggene publiseres også i papirutgaven i spalten «Brev til redaktøren».

Redaksjonen forbeholder seg retten til å foreta redaksjonelle endringer.

Forfattere av vitenskapelige artikler har tilsvarsrett, jf. Vancouver-gruppens regler.

\section{Re: Oslo 2014 fra studentenes perspektiv}

Stabursvik og medarbeidere har på invitasjon fra Tidsskriftet skrevet en kommentar med kritiske bemerkninger til innføringen av den nye studieplanen ved medisinstudiet i Oslo (1). Jeg har vært prosjektleder fra august $2014 \mathrm{og}$ har forståelse for at endringer skaper usikkerhet og at upopulære avgjørelser kan vekke frustrasjon og sinne. Jeg vil kommentere enkelte utsagn som jeg mener gir et fortegnet bilde.

Stabursvik og medarbeidere skiver: «Vi har hatt inntrykk av at informasjon er blitt holdt tilbake i påvente av at alle detaljer skulle falle på plass.» Jeg kjenner meg ikke igjen i dette. Mange studentrepresentanter har bidratt $\mathrm{i}$ arbeidet med studieplanen, inkludert i prosjektets styringsgruppe, og har hatt oversikt over status. Prosjektgruppen har forankret arbeidet og planer i styringsgruppen, har prioritert dialog og informasjonsarbeid høyt og har orientert om rammer og detaljer så snart disse forelå. Jeg har deltatt på semestervise møter med kulltillitsvalgte og på allmøter i regi av Medisinsk fagutvalg. De enkelte kull er fortløpende blitt orientert. Fristene for publisering av emner, informasjon om obligatorisk undervisning og eksamener er overholdt. Det vil være vanskelig å oppfylle alles ønsker om detaljert informasjon på et tidlig tidspunkt, før endelige beslutninger er tatt.

Med henvisning til overgangsordningen før fjerdeåret skriver Stabursvik og medarbeidere: «Måneden med ekstra undervisning og påfølgende eksamener ble for høstkullene tatt fra sommerferien.» Det er snakk om totalt to uker kortere sommerferie og ikke en måned, fordi den øvrige undervisningen i vårsemesteret ble kuttet. I 2015 ble en av ukene lagt i august, men i 2016 lå forholdene til rette for en løsning hvor undervisningen og eksamener ble avviklet i juni. Studentene på de aktuelle kullene får fri fire uker senere i studiet. Fakultetsledelsen og prosjektgruppen har stor forståelse for at den nødvendige overgangsordningen har vært en merbelastning.

Stabursvik og medarbeidere mener at informasjonen om overgangsordningen kom «svært sent». Den 17.11. 2014 ble det arrangert et allmøte for det første kullet, hvor datoer for undervisningen i juni og eksamener i august 2015 ble presentert. En løsning med eksamen i juli 2015 ble utredet, men vi konkluderte 27.11. 2014 med at dette ikke lot seg gjennomføre. Kullet fikk beskjed samme dag - syv måneder før den ekstra uken med undervisning i juni 2015. I mars 2015 ble det gjennomført en avstemming på kullet om en alternativ løsning. Flertallet, 66 av 76 studenter, stemte for å opprettholde de opprinnelige datoene. Det neste høstkullet fikk vite datoene nesten ett år i forkant.

Mitt hovedinntrykk fra møtene med enkeltstudenter, kull og medlemmer av Medisinsk fagutvalg er at vi har hatt en god og åpen dialog om en spennende, men krevende vei mot et bedre studium i Oslo.

\section{Jan C. Frich}

jan.frich@medisin.uio.no

Jan C. Frich (f. 1970) er professor ved Universitetet i Oslo.

Ingen oppgitte interessekonflikter.

\footnotetext{
Litteratur

1. Stabursvik J, Solberg IL, Lockert O. Oslo 2014 fra studentenes perspektiv. Tidsskr Nor Legeforen 2016; 136: 1191.
}

\section{Re: Behandling av gassembolier}

Det er prisverdig at det fokuseres på luftemboli relatert til prosedyrer (1). Som et av behandlingsforslagene anbefales venstre sideleie. Ved større luftembolier via venesystemet er dette antakelig riktig fordi det forhindrer at all luft samles i høyre ventrikkel og på den måten reduserer faren for lufttamponade av hjertet med komplett pumpesvikt som følge (fig 1). Ved lungepunksjoner er mekanismen ulik ved at luft kommer direkte i lungevenene/venstre hjerte og transporteres videre til aorta, koronarkar og cerebrale kar. Her er det viktig å forhindre at luften transporteres som store bobler og okkluderer koronararterier eller cerebrale kar. Derfor er det ytterst viktig at apeks av venstre ventrikkel plasseres oppover slik, at luften samler seg i trabekelverket av venstre ventrikkel og blir enten løst opp eller transportert videre i små bobler. En slik posisjon av venstre ventrikkel oppnås hos de fleste i ryggleie, men den sikreste posisjonering er i høyre sideleie, dvs. venstre side opp. På denne måten fanger venstre ventrikkel luftboblene som en omvendt bøtte (2).

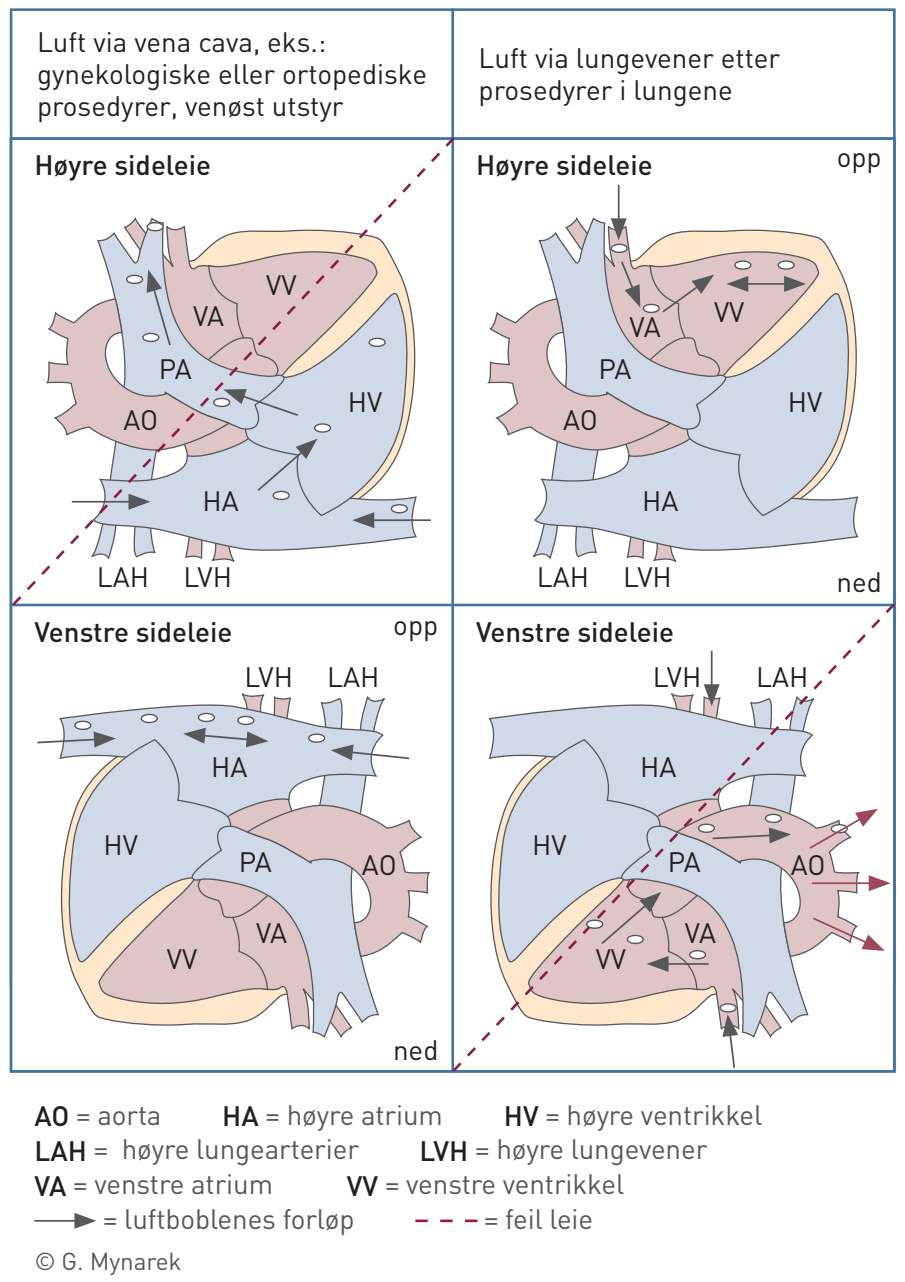

Skjemaet viser hvilket leie som er hensiktsmessig etter luftemboli via hhv. de store hulvenene eller lungevenene. Det er uansett hensiktsmessig å senke overkropp og hodet. Nødvendige førstehjelpstiltak bør dog ikke hindres av leiet 
Ved å legge pasienten i venstre sideleie vil venstre ventrikkel umiddelbart tømmes for luften som vanligvis transporteres rett til koronararteriene eller til hodet. Dette kan gi et fatalt utfall. Enda verre enn venstre sideleie er om pasienten settes opp - da er videretransport av luften til hjernen nærmest garantert. For å hindre at signifikante embolier oppstår, bør man redusere hoste som gir betydelige trykksvingninger intrathorakalt i den grad det er mulig. Man bør også bruke så tynne nåler som mulig, og vurdere å plugge stikkanalen når nålen trekkes ut. Ventilasjon av pasienten med økt trykk i luftveiene er også en risikofaktor. Etter punksjonen bør pasientene flyttes i sengen sin liggende med hodet lavt.

I Helse Sør-Øst har det vært fire fatale dokumenterte luftembolier relatert til lungepunksjon de siste 13 år, i tillegg fikk flere pasienter alvorlig nevrologisk sekvele. Luftemboli er heldigvis så sjelden at de fleste leger ikke har personlig erfaring med denne tilstanden, men det er den komplikasjonen av CT-veiledet lungepunksjon som har krevd flest liv i Norge de siste årene. Det er viktig at alle som utfører prosedyrer med fare for luftemboli setter seg godt inn i mekanismene og behandlingen. Når man kommer i den situasjonen er tiden knapp, og god forberedelse er den beste forutsetningen for å redde liv og helse.

Ellers bør man gi $100 \%$ surstoff, som angitt, for å redusere partialtrykk av nitrogen, og dermed boblens størrelse. Videre må transport til trykkammer skje så raskt som mulig. Luftemboli er potensielt like alvorlig som hjertestans og mistanke håndteres ved varsling av stansteamet.

\section{Georg Karl Mynarek \\ gmynarek@ous-hf.no \\ Gerhard Bosse}

Georg Karl Mynarek (f. 1961) er overlege ved Radiologisk avdeling, Oslo universitetssykehus, Rikshospitalet.

Ingen oppgitte interessekonflikter.

Gerhard Bosse (f.1967) er overlege ved Radiologisk avdeling, Oslo universitetssykehus, Rikshospitalet.

Ingen oppgitte interessekonflikter.

\section{Litteratur}

1. Skulberg AK, Mathisen LC, Vaagbø G. Behandling av gassembolier. Tidsskr Nor Legeforen 2016; 136: 1070.

2. Hare SS, Gupta A, Goncalves AT et al. Systemic arterial air embolism after percutaneous lung biopsy. Clin Radiol 2011; 66: 589-96.

\section{Re: Over 80 år og hjerteinfarkt}

Takk til Tidsskriftet for den hyggelige omtalen av After Eightystudien $(1,2)$. Vi har imidlertid behov for å kommentere Erik Øies lederartikkel, hvor han stiller spørsmål vedrørende seleksjonen av pasientene (3). Som leder av et av de rekrutterende sentrene kunne det være av interesse å høre Øies begrunnelse for bekymringen. Inklusjonen av pasienter ble utført av de rekrutterende sentrenes (lokalsykehus) eget helsepersonell. Ressurssituasjonen, holdninger og praksis - eller manglende interesse for å inkludere pasienter kan derfor ha påvirket inklusjonsprosessen. Om det har vært en felles systematikk i dette for alle inkluderende sentre, er vi svært tvilende til. Denne problemstillingen ble diskutert i en lederkommentar i The Lancet, med en noe annen vinkling og forståelse enn Øie gir uttrykk for (4).

After Eighty-studien har en eksplanatorisk og ikke en pragmatisk design, og det vil derfor alltid være en viss form for seleksjon i studier som dette $(5,6)$. Vår intensjon var å randomisere den store gruppen av veldig gamle hjerteinfarktpasienter som allerede var stabilisert og symptomfrie med medisinsk behandling. Komorbiditeten i studien var likevel tilsvarende som i «real life»-registerstudier for pasienter i samme aldersgruppe som enten fikk invasiv eller konservativ behandling. Videre valgte vi å redegjøre for absolutt hele populasjonen av hjerteinfarktpasienter over 80 år i studieperioden, fordi vi mente dette ville være av epidemiologisk interesse. Vi beskrev således en populasjon som er langt mer omfattende enn en standard screeningpopulasjon. At inklusjonen kun var på $11 \%$, som Øie hevder, er derfor feil (7). Pasientene som ikke ble inkludert av logistiske grunner skyldtes at vi ikke hadde studiepersonell tilgjengelig på de inkluderende sykehusene til enhver tid. Det kan også ha vært samtidighetskonflikter for personellet ved de inkluderende sentrene. Videre er det generelt svært utfordrende å gjennomføre kliniske studier av eldre pasienter, noe vi også fikk erfare, og som kompliserer bildet ytterligere $(7,8)$.

Alle komponentene i det primære endepunktet - hjerteinfarkt, behov for revaskularisering, hjerneslag og død - var i favør av invasiv strategi, men bare hjerteinfarkt og behov for revaskularisering var statistisk signifikant. Imidlertid var det også ca. $10 \%$ relativ forskjell i død og dobbelt så mange hjerneslag i disfavør av en konservativ strategi. Alt i alt gir dette derfor en signifikant forskjell i det primære endepunktet i favør av en invasiv strategi. Påstanden til Øie om at nytten av behandlingen bare gjelder pasienter under 90 år har man ikke grunnlag for å kunne uttale seg om, men man ser avtagende effekt ved økende alder.

Kostnadsanalyser er kompliserte og er under bearbeidelse, men kalkylene er mer komplekse enn det Øie gir uttrykk for i sin kommentar. Øie viser til Norsk hjerteinfarktregister, der $26 \%$ av pasientene over 80 år og 46 \% i aldersgruppen 80-84 år får invasiv utredning i Norge. Vi er ikke så sikre som Øie på at disse tallene tyder på en liberal invasiv praksis i Norge. Ved vår retrospektive gjennomgang av den nevnte populasjonen var det overraskende mange eldre som ikke ble vurdert for en invasiv strategi. Videre var den medisinske behandlingen av eldre ofte ikke i henhold til gjeldende retningslinjer eller medisinsk begrunnet.

Per i dag foreligger det god dokumentasjon på nytten av invasiv utredning hos yngre pasienter med gjennomgått akutt hjerteinfarkt uten ST-elevasjon. After Eighty-studien viser at også pasienter over 80 år er tjent med en invasiv strategi selv om det, som for alle pasienter, alltid må gjøres individuelle vurderinger i hvert enkelt tilfelle.

\section{Nicolai Tegn \\ nicklo@ous-hf.no \\ Michael Abdelnoor \\ Lars Aaberge \\ Knut Endresen \\ Lars Gullestad \\ Bjørn Bendz}

Nicolai Tegn (f. 1973) er lege i spesialisering ved Kardiologisk avdeling, Oslo universitetssykehus, Rikshospitalet.

Ingen oppgitte interessekonflikter.

Michael Abdelnoor (f. 1944) er tidligere forskningsleder i epidemiologi ved Senter for biostatistikk og epidemiologi ved Oslo universitetssykehus. Ingen oppgitte interessekonflikter.

Lars Aaberge (f. 1954) er overlege ved Kardiologisk avdeling, Oslo universitetssykehus, Rikshospitalet.

Ingen oppgitte interessekonflikter.

Knut Endresen (f. 1946) er overlege ved Kardiologisk avdeling, Oslo universitetssykehus, Rikshospitalet.

Ingen oppgitte interessekonflikter.

Lars Gullestad (f. 1951) er overlege/professor ved Kardiologisk avdeling, Oslo universitetssykehus, Rikshospitalet.

Ingen oppgitte interessekonflikter.

Bjørn Bendz (f. 1964) er overlege/førsteamanuensis ved Kardiologisk avdeling, Oslo universitetssykehus, Rikshospitalet.

Ingen oppgitte interessekonflikter. 